BMJ Paediatrics Open

\title{
Single-centre telephone survey on patients' perspectives regarding remote paediatric outpatient consultations in a district general hospital
}

\author{
Nilima Singh (D), Manas Datta
}

To cite: Singh N, Datta M. Single-centre telephone survey on patients' perspectives regarding remote paediatric outpatient consultations in a district general hospital. BMJ Paediatrics Open 2020;4:e000885. doi:10.1136/ bmjpo-2020-000885

- Additional material is published online only. To view, please visit the journal online (http://dx.doi.org/10.1136/ bmjpo-2020-000885).

Received 29 September 2020 Accepted 1 November 2020

Check for updates

(C) Author(s) (or their employer(s)) 2020. Re-use permitted under CC BY-NC. No commercial re-use. See rights and permissions. Published by BMJ.

Paediatrics, Mid South Essex NHS Foundation Trust, Chelmsford, United Kingdom

Correspondence to Dr Nilima Singh; nilima.singh@ meht.nhs.uk

\section{ABSTRACT}

During the COVID-19 pandemic, remote consultations became a new norm for paediatric outpatient clinics. The objective of this survey was to find patients' perspective on telephone consultations. 200 patients, who had remote consultations since April 2020, were surveyed and their responses were analysed. Almost half (98/200) of the patients or their parents preferred remote consultations mixed with face-to-face consultations; only a fifth (40/200) preferred exclusively face-to-face consultations; and approximately a third (62/200) preferred exclusively remote consultations. In conclusion, remote consultations are becoming a popular choice for patients, although there are limitations, especially in the context of safeguarding.

Face-to-face consultations are the norm for seeing patients in paediatric outpatient clinics. During the COVID-19 pandemic, this changed to telephone consultations due to the need for social distancing and minimising the risk of spread of infection.

We carried out a telephone survey in July 2020 on 200 patients who had telephone clinic consultations since April 2020, mainly to assess the future potential for remote consultations in paediatric follow ups, as well as for selected new patients who may not need physical examination. Patients were chosen from paediatric clinics, and we included everyone who answered the call, without any exclusion. No one declined the interview. A telephone survey provided instant results but was time-consuming due to low call pick-up rate. A postal survey was not sent out due to significant delay in postal services, costs involved and being labour intensive yet likely low yield. Patients or their parents were not involved in the design, conduct, reporting or dissemination plans of this survey. Parents responded on behalf of their children in most cases due to the child's age and shared their views (please see online supplemental appendix 1 for the questionnaire). Data was collected and anonymised for analysis.
Results of the survey (figure 1) showed that only a fifth of patients/parents (40/200) preferred exclusively face-to-face consultations. Approximately a third (62/200) preferred virtual consultations either by telephone or through video. Almost half (98/200) preferred a mixture of virtual (telephone/video) and faceto-face consultations with majority preferring face-to-face consultation initially and then virtual consultation follow-up.

In patients'/parents' own words, the main reasons for preference for exclusively face-toface consultations were regarding the need for examination of the child and ease of communication (box 1, section A). There were a variety of reasons for preference for virtual consultation, but the main themes were decreased risk of infection, convenience and time saving (box 1, section B). Parents also felt that this was a safe option as face-to-face review could be organised at a later date if needed.

In summary, although there can be limitations to virtual consultations, for example, lack of ability to examine the child physically and record their growth parameters, ${ }^{1}$ there are several advantages of virtual consultations as our survey results show. Remote consultations are particularly suitable for chronic conditions and may be appropriate for some new referrals, provided the patients are triaged appropriately. Virtual clinics can also support providers to meet increased demand. Recent data from the paediatric outpatient department showed that we were able to reduce the waiting periods significantly. Before

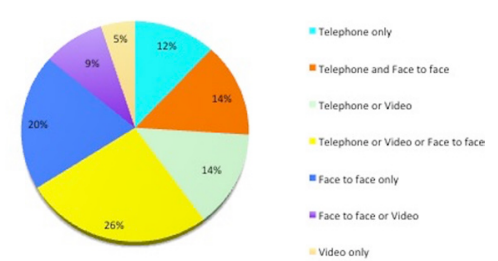

Figure 1 Patient's/Parent's preferences for clinic consultation. 
Box 1 Reasons for patient's/parents' preference for face

to face and remote consultations

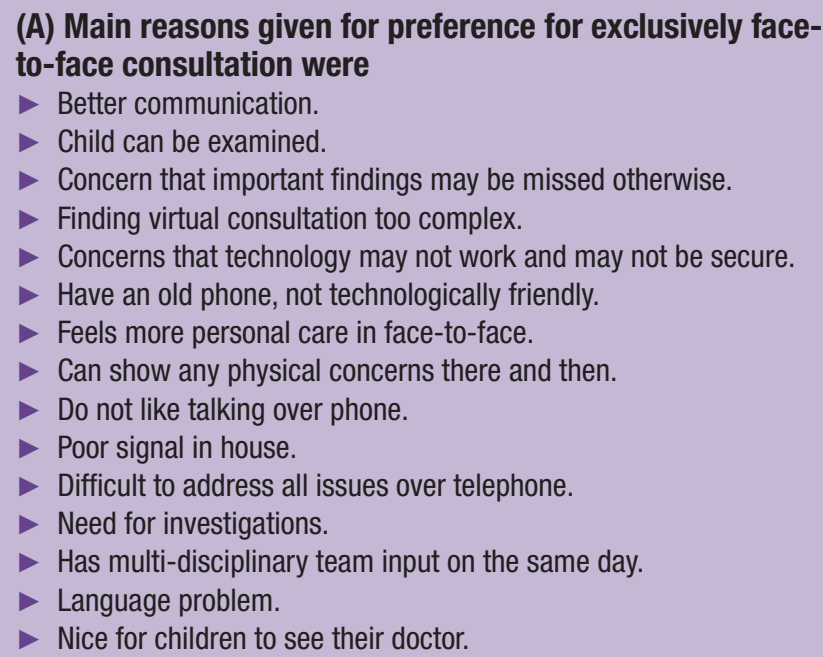

(B) Main reasons given for preference for remote consultations were

- As good as face-to-face.

- Still professional.

- Ideal for child's condition.

- Time saving.

- Convenient.

No parking fee or stress of driving.

- Saves transport difficulties.

Parent does not drive.

- No need to take time out of school.

- Examination not required for the clinical condition.

Option to arrange face-to-face consultation afterwards.

- Parent has chronic illness.

- Best for immunocompromised child, decreased risk of infection.

Serves the purpose.

the start of the pandemic, the waiting list for the follow-up patients in some of the clinics was delayed by up to 1.5 years, but as a result of virtual clinics, we were able to clear the backlog completely and to see children within the recommended time scale.

However, technology comes with its own challenges, especially in a paediatric setting; one needs to be careful whether virtual consultation will be appropriate in the context of safeguarding and effective in communicating well with children or young people. ${ }^{2}$

On balance, virtual consultations seem to be appropriate for and preferred by most children and parents, as long factors such as safeguarding and need for investigations or examination are taken into account carefully. The widespread introduction of virtual clinics has been a positive outcome from the pandemic, and this study suggests that virtual clinics are already a popular choice among parents.

Acknowledgements The authors thank the paediatric outpatient team at Broomfield Hospital.

Contributors NS conceived the idea for the research, designed the template for questionnaire, collected the data with initial help from nursery nurses in the paediatric outpatient department and prepared the original manuscript. MD supervised the project and the manuscript.

Funding The authors have not declared a specific grant for this research from any funding agency in the public, commercial or not-for-profit sectors.

Competing interests None declared.

Patient consent for publication Not required.

Provenance and peer review Not commissioned; externally peer reviewed.

Supplemental material This content has been supplied by the author(s). It has not been vetted by BMJ Publishing Group Limited (BMJ) and may not have been peer-reviewed. Any opinions or recommendations discussed are solely those of the author(s) and are not endorsed by BMJ. BMJ disclaims all liability and responsibility arising from any reliance placed on the content. Where the content includes any translated material, BMJ does not warrant the accuracy and reliability of the translations (including but not limited to local regulations, clinical guidelines, terminology, drug names and drug dosages), and is not responsible for any error and/or omissions arising from translation and adaptation or otherwise.

Open access This is an open access article distributed in accordance with the Creative Commons Attribution Non Commercial (CC BY-NC 4.0) license, which permits others to distribute, remix, adapt, build upon this work non-commercially, and license their derivative works on different terms, provided the original work is properly cited, appropriate credit is given, any changes made indicated, and the use is non-commercial. See: http://creativecommons.org/licenses/by-nc/4.0/.

ORCID iD

Nilima Singh http://orcid.org/0000-0001-5565-6566

\section{REFERENCES}

1 Thomason E, Hulikere S. Paediatric follow up telephone consultations: a new way of working? BMJ 2020.

2 NHS England. Specialty-Guide-Virtual-Working-and-Coronavirus-27March 2020, version 1; 2020. 